\title{
The Development of an Indigenous Knowledge Program in a New Zealand Maori-Language Immersion School
}

\author{
BARBARA HARRISON \\ University of Waikato \\ RAHUI PAPA \\ Te Wharekura o Rakaumangamanga
}

\begin{abstract}
In 1985, Te Wharekura o Rakaumangamanga initiated a Maori-language immersion program for children ages 5 through 18. In recent years, a program based on Waikato-Tainui tribal epistemology has been incorporated into the language immersion program. This article describes the community context and the language immersion and tribal knowledge programs. We consider the relationship of these programs to individual and tribal selfdetermination and to theories of minority achievement, particularly the work of John Ogbu. [Indigenous epistemology, Indigenous language maintenance, Indigenous education, New Zealand Maori]
\end{abstract}

This article describes the development of a program of traditional knowledge of the Waikato-Tainui tribe in a Maori-language immersion school located in Huntly in the central North Island of New Zealand. ${ }^{1}$ In the 1980s, Maori political action within the local community and at the national level resulted in the establishment of a Maori-language immersion program at the primary school level at Rakaumanga. ${ }^{2}$ In 1993, Rakaumanga added Year 9, the first year of secondary school, to its existing Maori-language immersion primary school. By 1997, all primary and secondary years and all learning areas except English were taught in Maori. From 1997 onward, Te Wharekura o Rakaumangamanga has provided Maori-language immersion instruction for 350 to 400 children, from Year 1 (age 5) through Year 13 (ages 17-18). ${ }^{3}$

When the immersion program began in 1985, the stated goals focused on maintaining the Maori language, providing children with knowledge and confidence in their heritage, and student achievement. During the first few years, the emphasis in the formal curriculum was on the development of instructional programs and materials for teaching and learning the various subjects of the curriculum in the Maori language. As the program expanded and more teachers from the WaikatoTainui tribe joined the staff, Waikato-Tainui knowledge and ways of knowing have been given increasing emphasis in the school program.

In 2002, the Ministry of Education introduced a new structure for secondary school education, wherein students gained academic credits toward the National Certificate of Educational Achievement (NCEA) as they moved through secondary school. NCEA provided greater opportunities for Rakaumanga to integrate Waikato-Tainui knowledge, histories, and ways of life into the seven essential learning areas mandated by the Ministry in its national curriculum framework. Rakaumanga school personnel saw their program as one that intertwined Maori knowledge with Western educational requirements. They believed that this program provided a strong basis for self-determination for students, individually and tribally, as well as an educational foundation for students who would become contributing members of the tribe and the broader New Zealand and global societies.

In this article, we describe the background of the Rakaumanga community, the establishment of the language immersion program, and limited self-determination

Anthropology and Education Quarterly, Vol. 36, Issue 1, pp. 57-72, ISSN 0161-7761, electronic ISSN 15481492. 2005 by the American Anthropological Association. All rights reserved. Please direct all requests for permission to photocopy or reproduce article content through the University of California Press's Rights and Permissions website, at http://www.ucpress.edu/journals/rights.htm. 
for schools in the New Zealand educational system. By limited self-determination we mean that each school board exercised options for their school but their options were limited by policies set at the national level. We present the rationale for and development of the program in Waikato-Tainui knowledge. We then consider the relationship of the Indigenous knowledge program to tribal self-determination and human rights and the contribution of anthropologists to tribal development. We conclude with a brief reflection on academic theories that have specifically and uniquely affected Rakaumanga's development.

The principal of Rakaumanga believed that Ogbu and Simons's (1998) model of cultural ecology was important in promoting understanding of the underachievement of Maori children. However, the model leaves Indigenous groups with questions of how to alter either the "system" on the one hand or the "community forces" on the other, and, even when there are changes in the cultural ecology, how to design programs that will allow Indigenous groups to express themselves as a people. The purpose of the present article is to offer insights into one Indigenous community's responses to these questions through their school's language immersion and Indigenous knowledge programs.

\section{Methods}

This article builds on previous publications about the school. Tuteao (1998) portrayed the history of the school in her master of arts of education thesis, and Harrison $(1987,1998)$ described the development of the primary school's Maori-language immersion program. Two additional master's theses have been based on research at the school, one examining mathematics achievement (Aspin 1994) and the other examining the professional development of mathematics teachers (Rogers 2003). These publications provide the context for the present discussion about the Waikato-Tainui epistemological components of the school's program.

During the 1990s, Maori academics began to focus on developing Maori approaches to educational research and theory. In particular, Linda Smith's 1999 book, Decolonizing Methodologies, has received international recognition for its contribution to Indigenous self-determination in research and education. "What researchers may call method, for example, Maori researchers in New Zealand call Kaupapa Maori research or Maori-centred research" (Smith 1999:125). We acknowledge the contribution of Kaupapa Maori research and have made every effort to ensure that the present article is, indeed, Maori-centered.

At the same time, each of us has contributed particular perspectives. Harrison conducted her first study at Rakaumanga in 1986-87 (Harrison 1987), and has maintained a continuing relationship with the school as a member of the Board of Trustees (Runanga), minutes secretary of the Runanga, and research coordinator. She has lived in the community for 18 years and has informally attended a large number of tribal, family, and school events. Papa is a member of the Waikato-Tainui tribe and has been a history teacher in the school's secondary unit for nine years, specializing in tribal histories. His day-to-day participation in the full range of the school's activities included meetings in 2003 with a curriculum development group that focused on the direction of the Year 13 course on Waikato-Tainui knowledge described in this article. Staff, Runanga, and community members contributed to the group. In 2004, Papa was the teacher of this course. His lifetime experience in the community and participation in tribal government provide a strong background of experience for his positions on tribal education.

This article is the result of collaboration between the authors and the school's Runanga. The request for the research and publication came from the Runanga, and all aspects of the work were discussed and reviewed by the Runanga and members of the school staff. For the present article, we have relied on basic methods of ethnographic research in education. We reviewed minutes of the Runanga meetings from 1990 to 2002 as well as previous publications about the school and literature on Indigenous epistemologies in school curricula. Information about Waikato-Tainui 
knowledge in the school program came from Runanga meetings and from interviews between the authors, other staff members, and young adults who were students in the secondary school during the first decade of its operation. Drafts of this article were reviewed by each individual who made a contribution as well as by all members of the Runanga.

\section{The Rakaumanga Community}

"The Polynesian ancestors of the Maori people had been living in Samoa and Tonga over a thousand years when they began undertaking a series of long ocean voyages of discovery and settlement of islands of the Great Ocean of Kiwa.... New Zealand was the last to be settled, around AD 800" (Walker 1990:24). Contemporary Maori tribes take their names from the waka (canoe) that brought their ancestors to New Zealand hundreds of years ago. The Tainui confederation of four tribes (Waikato, Maniapoto, Hauraki, and Raukawa) inhabits the central North Island of New Zealand. Many children of Rakaumanga are descendants of the Waikato tribe of the Tainui canoe, referred to in recent official documents as Waikato-Tainui. In 2004, the Waikato-Tainui tribal enrollment was approximately 49,000, making it one of the largest tribes in New Zealand.

The first European ship to visit New Zealand was that of Abel Tasman in 1642. More than a century passed before James Cook began to explore the New Zealand coastline in 1769. Captain Cook's reports opened the country to European trade and settlement. In 1835, British resident James Busby convened a meeting at Waitangi of 34 Maori chiefs to sign a declaration of confederation and independence. "In the first clause of the declaration, the chiefs declared New Zealand to be an independent state under the name of the United Tribes of New Zealand" (Walker 1990:88). Less than five years later, the Treaty of Waitangi was drawn up and signed by Maori chiefs on February 6, 1840. For the Waikato-Tainui tribe, the declaration of independence retained its significance because their ancestors signed this declaration but did not sign the Treaty of Waitangi. Nationally, the Treaty of Waitangi became known as the founding document of New Zealand, and the earlier declaration has been largely ignored.

There were versions of the Treaty of Waitangi in Maori and in English, with resulting disagreement about the meaning of the treaty's three clauses. However, Walker (1990:93) asserts that the version signed by Maori confirmed their own sovereignty while ceding the right to establish a governor in New Zealand to the British Crown. In recent years, the treaty has been interpreted to mean that partnership in decision making between Maori and Pakeha (non-Maori) must be part of the formal structure of all public affairs, including education.

The signing of the treaty opened New Zealand for continuing European settlement and trade. Disputes between Maori and Pakeha over land led to warfare, first in the northernmost region of the country and eventually throughout most of the North Island. In 1858, Maori tribes united in selecting a single chief, Potatau Te Wherowhero, who had genealogical links with all the major tribes. The political and spiritual movement he led has been called the King Movement or Kingitanga, and the Waikato-Tainui people consider themselves to be the guardians of this movement.

In 1863, the British and settler armies invaded the Waikato region, driving King Tawhiao (son of Potatau Te Wherowhero) and his followers out of Waikato and into a region that became known as the King Country. The government confiscated 1.2 million acres of Waikato-Tainui land and opened that area for settlement. In 1867, King Tawhiao sought to negotiate the return of the land. The King and his followers returned to the Waikato region in the 1880s, but only small parcels of land were left to them. ${ }^{4}$ Negotiations for the return of land continued for more than a century through several generations of leaders of the King Movement. A settlement was finally signed in 1995, but only a small percentage of the land confiscated was returned to the tribe (McCan 2001). 
Although the Maori struggles against colonial hegemony persisted in many regions of the country throughout the 20th century, a new era of national Maori activism began in the 1970s. One outcome of this movement was the establishment of the Waitangi Tribunal to consider Maori grievances against the government. In 1985 a claim relating to the Maori language was brought to the tribunal. English had become the country's dominant language, in large part because education policies mandated that English be the language of instruction in all schools from the mid19 th century onward. The tribunal ruled in favor of the claimants in 1986, and eventually the Maori Language Act was adopted, making Maori an official language of New Zealand and opening the way for government-funded Maori-language education programs. The early 1980s saw the introduction of Te Kohanga Reo, Maori immersion "language nests" for preschool children. When the first groups of Kohanga Reo children reached the age of 5 , the government came under pressure to provide primary school education for them in the Maori language. The first Maori immersion primary schools and bilingual units were established in the mid-1980s.

Following World War II, many Maori migrated to urban areas where work was available. By the end of the 20th century, 80 percent of the Maori lived in cities. Another major trend has been the rapid expansion of the Maori population. The 1896 census revealed only 42,113 Maori in the entire country, but by 2001 the number had grown to 604,110 (Statistics New Zealand 2001). During the same period, land and other natural resources had been confiscated, sold, or lost by other means so there seemed little possibility for most Maori to maintain their precontact economic systems in the 21st century. It seemed evident that most Maori children would need to acquire knowledge and skills for active participation in the mainstream entrepreneurial economy.

One Ministry of Education policy established in the 1990s mandated the collection of socioeconomic information on each school's community in order to classify each community's socioeconomic level. Each school has been classified on a scale of one to ten, with one representing the lowest socioeconomic level. Rakaumanga was classified as a "decile 1" school, at the lowest end of the socioeconomic scale.

\section{The Establishment of the Immersion Program at Rakaumanga School}

The mission schools of the 19th century taught the standard subjects of the English school curriculum but the teaching was done in Maori (Walker 1990:85). With the 1867 Native Schools Act, which mandated instruction in English, the state assumed complete responsibility for the cost of the schools. Rakaumanga was established as a Native school in 1896 but joined the mainstream New Zealand school system in 1969. Even after Rakaumanga joined the mainstream system, the children attending were predominantly Maori.

In the 1970s, the community of Waahi and the tribal trust board protested against the site chosen for a power station. The protests carried over into political action to establish a Maori language primary school at Rakaumanga. In 1985, the Rakaumanga community gained formal approval from the Ministry of Education to establish a Maori-language immersion program. That year's class of 5-yearolds was composed of children from the local language nests and as this group progressed through primary school, a new Maori immersion class was added each year until 1992, by when all primary school classes were taught in Maori. The home language of virtually all Rakaumanga children was English, and most radio and television broadcasting was in English. As a result, Rakaumanga children learned to speak English fluently in the home and wider community. English literacy was taught as a separate subject at Rakaumanga from Year 4 upward.

The Rakaumanga school staff and community realized that for children to maintain and develop Maori language fluency and literacy, they would need to be taught in Maori throughout their secondary school years. In addition, high percentages of Maori students in mainstream schools dropped out or failed before they completed Year 13. Parents of the Year 8 students were adamant that they wanted their children to continue to be educated in a Maori immersion school. 
The Ministry of Education was less than enthusiastic about Rakaumanga's plan. Two other schools, one in Auckland and a rural school on the east coast, also were agitating for the right to establish secondary units in association with their immersion primary schools. Eventually, political action and argument led to the development of wharekura (combined primary and secondary schools) in all three locations as well as in other locations around the country. By the end of the 1990s, Te Wharekura o Rakaumangamanga campus included a science laboratory, home economics unit, expanded library, multipurpose hall, sports fields, additional classrooms, and a gymnasium. With occasional exceptions, all staff members were of Maori descent. Ministry of Education regulations stipulated that all classes could be taught in Maori but the school was required to follow the same national curriculum framework mandated for all New Zealand schools.

\section{Limited Self-Determination within the New Zealand Education System}

Reforms in the New Zealand educational system during the 1990s and early 2000 s resulted in a national system that allowed each school board to exercise options for their school, but options were limited by policies set at the national level. Each school had its own board of trustees elected from the local community. The trustees selected the principal and teachers for the local school and made certain decisions about the curriculum and expenditures, but three agencies established and assessed education policy at the national level. The Ministry of Education determined policy. The Education Review Office conducted regular reviews of each school's operations to ensure that it was operating within national policy. The New Zealand Qualifications Authority conducted annual assessments of the progress of secondary school students toward the various levels of the NCEA and operated accreditation systems for schools and institutions of higher education. Because of national policy deriving from the Treaty of Waitangi, each of these agencies had a section staffed primarily by Maori that dealt specifically with policies and practices that affected Maori students.

Each local school had to align its curriculum with the national curriculum framework, which included seven essential learning areas: language and languages, mathematics, science, technology, social sciences, arts, and health and physical well-being. Most schools taught in English, with Maori or another language taught as a separate subject. However, in 2003, the Ministry of Education's annual report on Maori education stated that there were 90 schools designated as immersion schools. There also were 340 schools designated bilingual or schools with immersion or bilingual classrooms, so that 21,520, or 14.1 percent, of Maori students were receiving 31 percent or more of their schooling in Maori (Ministry of Education 2003:Appendix 3).

All secondary schools had the option of selecting NCEA credits from the mainstream curriculum or developing their own units, which had to be approved by the New Zealand Qualifications Authority. Schools that taught subjects in Maori could arrange for the national assessments to be administered to students in the Maori language.

\section{Resources and Rationale for the Inclusion of Waikato-Tainui Knowledge in the Curriculum}

Anthropologist Dame Anne Salmond has argued that Maori epistemology was and is a complex and open system. Drawing on her extensive fieldwork and written accounts from the 19th and early 20th centuries, Salmond (1985:240) describes the meanings of Maori terms related to knowledge acquired by "familiarity and the exercise of intelligence" as well as ancestral knowledge. She notes that the cosmological theories and historical accounts of different tribal districts and major thinkers varied, and that debate on these differences by learned experts was one of the great chiefly pleasures (Salmond 1985:242,248). According to Salmond, one 
means by which traditional knowledge was transmitted from generation to generation involved taking even the youngest children to public assemblies, where they heard all that was said about topics of public interest. She finds no evidence that Maori logic differed in any essential way from European reasoning (Salmond 1985:253).

Salmond also describes the impact of European colonization and schools on Maori epistemology. The colonial literature contains "comments on [Maori] intelligence" and claims that Maori lacked knowledge and were waiting only to be enlightened (Salmond 1985:256). However, "most Maoris were interested, but not intimidated by manifestations of western civilization, and they adopted European ideas and practices as it suited them" (Salmond 1985:258).

The introduction of schools allowed Maori children to acquire Western literacy and knowledge but had a devastating impact on Maori language and epistemology. "There is a harsh disparity between the evidence of Maori philosophical speculation and debates in the 1840s and 1860s, and European accounts of Maori intellectual capacities in the same period: a disparity which became institutionalized with the development of Native schools, and the suppression of Maori language and culture in education" (Salmond 1985:259).

The Tainui tribal confederation was fortunate that, in the early 20 th century, Pei Te Hurinui Jones began to collect Tainui tribal histories that tell of the people and events of this tribe over hundreds of years. These are among the most highly valued components of Waikato-Tainui traditional knowledge. Jones was born in 1898 and began recording traditional stories of Tainui while a young man. He had little formal education but worked for the Maori Affairs Department and occupied many pivotal positions in Maoridom. Some of his early papers were published in the 1940s and 1950s (Jones 1945, 1958), and his biography of King Potatau was published in 1960, but the major collection of his work was edited and annotated by Emeritus Professor Bruce Biggs for publication in Maori and English (Jones and Biggs 1995). Although Kelly (2002) published an extensive Tainui history in English, Biggs (1995:2) claims that much of this was written by Jones and used without authority or proper acknowledgement. "For Pei Te Hurinui the traditions record the history of the tribes, and are not, as some anthropologists might claim, an elaborate social charter justifying the social and political order that existed when, or at some time before they were first recorded" (Biggs 1995:6). Jones was awarded an honorary doctorate by Waikato University in 1968 and died in 1976.

Biggs (1995:6) refers to the work of Robertson, who examined the traditions of different tribes and found the Tainui tradition to be consistent, with a convincing sequence. Biggs concludes that "Maori tribal traditions are not located in some timeless past but are invariably diachronic narratives linked precisely to detailed genealogical lattices defining a chronology that is internally consistent and in conformity with biological constraints" (1995:7). In addition to the work of Pei Te Hurinui Jones, the Jones and Biggs (1995) bibliography contains a lengthy list of publicly accessible manuscripts, as well as works in the private collections of the King Movement and tribal authority. Other publications, written by approved visitors to the tribe such as McCan's (2001) history of the land claim, also are available, and there is considerable unrecorded Waikato-Tainui knowledge maintained in oral traditions and through traditional activities such as eel fishing in the Waikato region. Thus, staff members of Te Wharekura o Rakaumangamanga have a wide range of Tainui resources upon which to draw for the school curriculum.

The Rakaumangamanga principal, teachers, and some members of the Runanga have attended international conferences on Indigenous education, including the World Indigenous Peoples Conferences held in New Zealand, Australia, Canada, and the United States. There they have shared their experiences and learned about the efforts of other Indigenous peoples to incorporate their languages and epistemologies into school curricula (see, e.g., Barnhardt and Kawagley 2004, this issue). Awareness of these programs has been of interest to Rakaumanga, but the major 
impetus for the Rakaumanga effort to incorporate Waikato-Tainui knowledge in the school program has come from the local community.

For more than a century, Rakaumanga has been located within walking distance of Waahi Marae. (A marae is a Maori community center.) Waahi is one of the major centers of the King Movement and a primary residence of the present leader of that movement, Te Arikinui Dame Te Atairangikaahu, and her closest relatives. Many Rakaumanga children are descendants of families who have supported the King Movement for nearly 150 years and who intend to continue that support in the future. These families view the King Movement as the spiritual and political center of the Waikato-Tainui people.

The proximity of Rakaumanga to Waahi Marae brings with it unique circumstances that foster this community's motivation to include traditional tribal knowledge in the school program. The students' tribal backgrounds, genealogies, and histories all flow from the people in the ancient Tainui canoe; the children are living proof of the value of the Waikato-Tainui way of life. Realizing that elders who possess tribal knowledge were passing away, and that traditional methods for transmitting tribal knowledge were not functioning as they had in the past, the staff and community believed that the school needed to revive Waikato-Tainui epistemology so that they would not become "standardized" with other tribes, subtribes, or tribal confederations. Staff and parents also believed that children need confidence and a strong inner foundation about their origins and tribal identity. The school's vision is for its graduates to retain this identity; staff and parents want their children to graduate with various degrees, becoming professors, doctors, or lawyers who are Waikato-Tainui, well versed in their own backgrounds first so that they can make significant contributions to New Zealand and the world.

\section{Epistemology of Teaching and Learning}

In the Maori language, one verb-ako-means both to teach and to learn. For Maori teachers, teaching and learning are interrelated processes with no clear distinction between them. Staff at Rakaumanga share a holistic view of the school's role in fostering the students' confidence, spirituality, and physical well-being as well as their academic development. Because of this holistic view, there is no clear distinction between the formal curriculum and the extracurricular activities. Staff members attempt to integrate learning experiences to promote the holistic wellbeing of students.

Students are well aware of the holistic vision of the school staff. One young man who completed all of his schooling at Rakaumanga reflected:

Like I say, we're just one big family, not just amongst ourselves but even with the teachers, too. We had a real good relationship with all our teachers, and we knew the line, you know, there was a line between how much friendship we had during school, and we couldn't get away with everything like that, but we were real tight. And outside of school, we knew that we could go to any one of them, and they would help us out with anything we wanted to do, you know with life, and school, and work.

\section{Development of the Waikato-Tainui Program}

When the immersion program began in 1985, the primary emphasis was on the revitalization of the Maori language. There were few teaching resources available in Maori so initial efforts focused on translating English resources into Maori. The early result was a curriculum that was Western in many respects but was taught in Maori.

More recently, staff members have observed that the use of the Maori language has been growing throughout the country. During the past 25 years, the Maori language has been introduced at all levels of the education system and in many other organizations and agencies. Maori immersion "language nests" for preschool children number in the hundreds. The national early childhood 
curriculum requires that every early childhood provider includes Maori language activities in their programs. In most regions, at least one Maori immersion school has been established. The universities and polytechnics-mainstream as well as Maori-operated-have established Maori-language courses. Schools (including Rakaumanga) and marae offer formal and informal Maori-language classes for adults. Maori training programs have been introduced for mainstream and Maori employees in several government agencies, and the courts employ Maori translators and interpreters. Maori Language Week is held every year, sponsored by the government, and is celebrated nationally with a range of events. Mainstream newsreaders offer Maori greetings at the beginning and end of daily newscasts. There are news broadcasts and current-affairs and youth programs in Maori on mainstream television, as well as tribal radio stations. A Maori television station began broadcasting in 2004. Rakaumanga teachers have good reason to believe that the Maori language is slowly re-entering the homes and communities as more parents and media expand the use of Maori at home.

For example, during the week of September 20, 2004, news media reported that the Minister of Education made a speech to a group of new school principals saying that in some schools, powhiri (Maori welcoming ceremonies) were taking too much time and girls were not given the opportunity for equal participation. In the days following, mainstream television and radio current-affairs programs discussed the Minister's comments. Newsreaders, presenters, and panel members of European descent did not define powhiri for the audiences; they assumed that listeners and viewers would know what a powhiri is and its place in schools.

As staff members became comfortable that students were receiving quality education in the Maori language, they looked at ways to foster the intellectual, social, physical, spiritual, and cultural attributes of an ideal Waikato-Tainui person. Staff members believed that students need to be well versed and confident in their own history and ways of speaking, so Waikato-Tainui knowledge became a very strong focus over the years.

From the beginning of the immersion program in 1985, teachers included activities, social structures, and protocol they belicved to be appropriate for WaikatoTainui schooling. It has been essential, for example, for visitors to be welcomed into the school community with formal welcoming ceremonies. The entire school participates in daily prayers in Maori at the opening of the day, before lunch, and at the end of the day. Teachers are addressed as whaea (mother/aunt) or matua (father/uncle), and classes are organized into three multigraded "extended families." Some instructional and social activities are regularly structured so that older students help younger students, reflecting the Maori value of the older siblings assisting and being responsible for younger siblings.

Each year, students and teachers participate in the major events of the King Movement at nearby Waahi Marae and other marae in the region. School personnel consider this participation to be essential to their program. Academically, the school has conducted large studies of the local region and the King Movement. Students have researched the history of the sacred mountain of Waikato-Tainui, the history of Kawhia (the resting place of the ancient Tainui canoe), and the history of the Waikato River. As a culmination of studies about the river, they produced a story of the flowing of the river from Tongariro Mountain in the central North Island to the sea.

When students reach the senior levels, there is significant emphasis on WaikatoTainui knowledge and histories. Students have studied geographic features of the Waikato-Tainui region, also learning Waikato-Tainui place names and the origins of those names. In Maori-language classes, students have learned about dialectical differences among the Maori, contrasting Waikato-Tainui with the dialects of other tribes. In English, translated historical stories of Waikato-Tainui have been used. In art, some students have completed traditional carvings and studied the reasons those carvings are appropriate for the school.

Every year in October, there is a gathering of Maori King Movement followers at Waahi Marae. Rakaumanga students attend every year to observe the elders 
and listen to the speeches. Rakaumanga girls serve in the kitchens and dining hall as their great-grandmothers, grandmothers, and mothers have done in the past and continue to do today. In May of each year, a contingent of the school attends celebrations at a marae 10 miles distant that mark the anniversary of the Maori Queen's Coronation. Students observe, listen, and sometimes participate. Each year, the school has held camps in Waikato-Tainui historical places. In 2003, the camp was at Kawhia, the site where the ancient Tainui canoe is buried. There are several historical sites in the area, enabling students to acquire substantial information about Waikato-Tainui people during this camp.

Prior to NCEA, the secondary school program was highly structured by the Ministry of Education. With the introduction of NCEA, the school has been given wider berth. Using the achievement standards for NCEA, the school has aligned more Waikato-Tainui knowledge with more facets of the program, including sport and recreation, art, English, and science. It has thus become easier to intertwine Maori knowledge with Western educational requirements.

Programs written in the Maori language in content areas such as mathematics and science have been designed at the national level, but there has not been (and is not likely to be) a national program to incorporate tribal knowledge into school curricula. Neither the political situation nor the funding situation presents a favorable context for developing a national program of tribal knowledge. However, each school can design the Maori or tribal content of its program, as Rakaumanga has done.

Although Rakaumanga's incorporation of Waikato-Tainui knowledge is unique, it is not necessarily exclusive. Other Maori-language immersion secondary schools with Waikato-Tainui students may use Rakaumanga's activities or achievement standards as part of their curriculum, but schools in metropolitan areas serve students from several tribes. It is expected that the urban schools will incorporate a host of specializations from other tribal areas. For Rakaumanga, the founding principles have been the two major Waikato-Tainui institutions: Waikato and the King Movement. Schools in other areas are likely to base their programs on a broader Maori view.

\section{The Waikato-Tainui Course for Year 13 Students}

In 2003, the Rakaumanga staff developed 17 achievement standards reflected in instructional units to be offered to Year 13 students (students in their final year of secondary school). As students complete each standard, they are granted variable credits toward the NCEA. Here we present a summary of topics from the Year 13 course as examples of the traditional knowledge that school staff perceived to be essential for their students and as examples of the types of knowledge that the Ministry of Education and the New Zealand Qualifications Authority recognize as "legitimate" for secondary school instruction. It is important to remember that this course is only one of the courses that Year 13 students undertake. With the exception of English, courses in other essential learning areas follow mainstream achievement standards but are taught in Maori.

The Year 13 course in Waikato-Tainui knowledge begins with two achievement standards related to tourism intended to teach traditional histories relevant to particular tourism attractions and marae protocol in a tourism context. The design for the first term of the school year also includes standards to ensure that students demonstrate knowledge of customs and protocol related to the King Movement and other traditional Waikato-Tainui gatherings.

In the second term, the course focuses on the Waikato-Tainui dialect, histories, traditional chants, and proverbs. English translations characterize these histories as myths and legends, but for Waikato-Tainui people, this is their history. For example, when people speak of their ancestor, Tane, and his supernatural feats, they understand them as occurring in another time and space. According to Salmond, there is a long-standing tradition of Maori thinkers dealing with alternative accounts 
of history and cosmology. "It seems to me indisputable, from the evidence of the ... tradition and of debating on the marae, that Maori tribal thinkers were acutely aware of alternative cosmological and historical accounts, and that they had developed conventions for dealing with these" (Salmond 1985:253).

The concept of guardianship is central to Maori relationships with the natural world, and this concept has an important place in the course. Waikato-Tainui guardianship is spiritual, involving guardians of each realm within the Maori sphere. Part of that guardianship involves knowing why guardians were placed in different areas, what they look after, and their relationship to people. People also are important guardians of the natural world. One teacher provided this example of relevant guardianship and history:

Just like the story about Rahui Pokeka. How did it get its name? It had something to do with the lakes in the area and the tuna eels. They were really diminishing and they put a ban, someone, a tohunga [expert] put a ban on fishing, and by placing a piece of flax from his raincoat, which is a pokeka, and tying it to a rakau [stick] and sticking it into the lake and telling the people not to go and fish until that pou [marker] was gone. And, you. know, he had handed it down. So, the rahui [prohibition] was lifted, the tapu [sacredness] was lifted, the ban was lifted, and the place was called Rahui Pokeka, which is Huntly [a town]. So, those sorts of things, they're history, they mean a lot to us, and I think it's important to hand that on to our kids.

Traditional chants are a part of the course because of their significant content. Within the ancient songs are the histories, the language and terminology used by Waikato-Tainui, references to rules, and place names.

Proverbs also are important to all Maori tribes. For Waikato-Tainui, the proverbs of King Tawhiao (the second Maori King who led the tribe through most of the second half of the 19th century) have special significance. When King Tawhiao spoke, it was taken as a guiding principle to the people. His prophetic sayings were grasped and held by the people. When prophecies came to fruition, the people repeated those references, which were broad enough to meet many criteria and many different situations as well.

Students in the second term undertake study of relationships between Waikato-Tainui and other Maori tribes, subtribes, and confederations. Genealogies are of huge importance as links between tribes. For example, in ancient times, the marriage of Turongo and Mahinarangi connected the royal line of Waikato-Tainui with that of the tribe of the east coast of the North Island. That point of reference joins the two peoples together. The course also explores traditional and contemporary Maori religions and, through Indigenous conferences and other linkages, examines the relationships between Waikato-Tainui and other Indigenous peoples.

In the third term, the course includes study of Maori leaders and Maori in national politics as well as knowledge pertaining to Tainui, the confederation, and its people. The plan for the final section on Tainui included construction of marae profiles; in-depth examination of a tribal governance structure; discussion of migration patterns, Polynesian settlement, and cultural comparisons across the Pacific; the Tainui confederation, origins, prayers, and people; and use of Maori communication skills to present ideas.

Teaching materials for this course include not only texts and manuscripts written by Tainui authorities, but also elders still versed in Tainui knowledge. Knowledgeable elders come into the school to sit and speak with students, just as this knowledge has been passed down through the generations via oratory and historical narratives.

The Year 13 course represents a new structure for the transmission of traditional knowledge, a structure quite different from those used by Waikato-Tainui people in precontact times. Teachers recognize this difference and the fact that for students to be well versed in traditional knowledge, they must rely on learning in the home and on participation in traditional community functions as well. 


\section{Kapa Haka, Speech Competitions, and Sports}

On the assumption that their educational program should focus on the holistic development of the social, physical, spiritual, and cultural attributes of students as well as their academic achievement, some school activities are not part of the formal curriculum, although they are considered essential. These include kapa haka (Maori performing arts), speech competitions, and sports.

Kapa haka is included in the program of every New Zealand school with a Maori focus, but it is often misunderstood by mainstream educators, who have been quoted in the media saying they believe that kapa haka detracts from students' academic achievement. Rakaumanga staff members believe the opposite to be true: Kapa haka, a conditioning of the mind, body, and spirit, contributes to children's holistic development, including their academic achievement.

Kapa haka instruction begins in the preschool language nests and continues throughout children's school years. Many adults participate in cultural performance groups as well, competing in biannual regional and national competitions. The judges of these competitions are the most highly respected and knowledgeable experts on Maori language and culture.

A primary reason for including kapa haka in the Rakaumanga program is that it instills in students the self-confidence to perform the tribe's historical chants in front of others. Kapa haka also allows teachers to incorporate particular WaikatoTainui words and phrases. The physical stance of performers is different from that of other tribes as well.

A variety of activities are associated with kapa haka. Kapa haka performances are a part of every school event (end-of-the-year prize giving, welcoming visitors, and so on). The school's kapa haka groups perform at marae events and events associated with the King Movement. The school's junior and senior kapa haka groups have entered regular regional and national competitions. Competing requires travel to competition sites, which in turn requires fund raising by students and their parents. Fund raising through raffles, school galas, and fairs, brings parents into school activities and helps students learn basic financial planning, accounting, and organizational skills. One young adult described the year-long fundraising activities for a trip for her kapa haka group to Perth, Australia, when she was in Year 11 in 1995:

I know we just had stalls at the galas, discos, raffles, heaps of them, though, hangi [a meal cooked in the traditional underground oven]. We had all kinds of things ... We not only had to help with the group fundraising, we had to get our individual fundraising as well, so some of the students that went had fundraising, raffles, and all that, alongside of the group fundraising, so it was pretty busy.

She then described the range of learning activities that she and her group experienced during the actual travel to Australia:

Those trips were based on, what's the word, cultural learning for Maori and Aboriginals, 'cause we were taken to different places where we would learn about what they were doing to kecp their culture alive... Like we went to radio stations and we had some Aboriginal people come and we had a concert kind of thing. We went to their schools. We went places like Te Puni Kokiri [Ministry of Maori Development], but for Aboriginal people.

The promise of travel to sites on the North and South Islands and overseas also keeps students' interest focused on school. When traveling within New Zealand, students typically stay on the marae of other tribes, learning their relationships to these tribes and something of their history and customs.

Some students have traveled to the regional and national Manu Korero speech competitions so that their kapa haka group could support the school's speakers. The secondary teachers' union, the Post-Primary Teachers Association, and the Maori Education Trust have sponsored annual speech competitions, called Manu 
Korero, for Maori students, in which students compete in Maori or English. Over the years, Rakaumanga students have won all the major awards. In 2003, the national competitions were held in Wellington, and Rakaumanga was linked by video so that students on campus in Huntly and those on site in Wellington could support the school's speaker, who won the national award in English. Students do not receive credits toward the NCEA for their participation in kapa haka or in speech competitions, but nearly every student in the school participates, and all school participants believe these are essential parts of the school program.

Sports is another after-school activity that demands a great deal of students' and teachers' time but helps maintain students' interest in school, self-confidence, and holistic development. Rakaumanga cooperates with Huntly's mainstream high school and the local rugby league club because, as a small school, Rakaumanga cannot always generate the numbers for teams of its own. Girls play netball and boys play basketball and rugby league. One former student described the association between rugby league competition and kapa haka:

We did traveling with league, to Taranaki, Auckland, Tokoroa, Putaruru ... playing different teams all over the place, and brought out another side to the boys, another unity apart from kapa haka.... It kind of gave us the feeling we were putting what we do in kapa haka into action. 'Cause we like to get out there and do the haka [war dance] and act all fierce, but can you really be as hard as you say you are in your haka? We trained hard and played hard, but, you know, not dirty at all, nothing like that, just hard.

\section{Self-Determination and Human Rights}

Rakaumanga staff members believe that the Year 13 Waikato-Tainui course provides students with the ability to exercise individual self-determination and confidence in knowing their own background. This background becomes a springboard for further education or vocations. The course offers the students the opportunity to be Waikato-Tainui first and Maori second, an important distinction because of the way the country has been shaped over the last 160 years: It has always been about partnership between Europeans and Maori. In the view of at least some school staff, self-determination involves Waikato-Tainui working for Waikato-Tainui. One of the key phrases within the school, especially for the principal, is that people are Waikato-Tainui's greatest resource. The Waikato Raupatu Settlement of 1995 reinforces the notion that Waikato-Tainui are working for their own self-betterment first, just as other tribes are working to better their people first. At the same time, Waikato-Tainui leaders worked with other tribes throughout the 1990 s to realize settlements for those tribes.

Staff members realize that, under the United Nations Draft Declaration on the Rights of Indigenous Peoples, Indigenous people have the right to work within their own educational structures and for their own self-determination. The Rakaumanga staff and community want their children to learn about themselves, their way of life, and their dialectical differences so that the tribe will never again flounder. They want many people to hold this knowledge so that when knowledgeable elders pass on, the knowledge remains. Rakaumanga views this as a fundamental human right, one that allows them to fashion their own destiny. If this entails creating their own unit or achievement standards, they are willing to do this.

Waikato-Tainui people have discovered that at least some anthropological research has been beneficial in achieving tribal goals. The work of Salmond (1985) and Ogbu (1978; Ogbu and Simons 1998) are examples of research that has helped members of the mainstream society better understand Indigenous cultural groups. Two distinguished Waikato-Tainui leaders have completed graduate work in anthropology. Sir Robert Mahuta studied anthropology at Oxford and his daughter, Nanaia Mahuta, Member of Parliament for the Tainui electorate, holds an M.A. with honors in social anthropology from Auckland University. Sir Robert has invited a number of researchers, including educational anthropologists, to work with the tribe. The local community expected those researchers to contribute to local 
development-for example, collaborating with tribal members to establish maraebased health programs, vocational training programs, scholarship programs, development plans, and other projects. Harrison and a team of Tainui educators used educational anthropological research in the formulation of the Tainui education strategy (Tainui Maaori Trust Board 1991). Tainui's education strategy was the first in New Zealand, and was used as a model by other tribes. All of these collaborative projects contribute to tribal self-determination.

The American Anthropological Association Code of Ethics (AAA 1998) calls on anthropologists "to consult actively with the affected individuals or group(s), with the goal of establishing a working relationship that can be beneficial to all parties involved." As long as educational anthropologists abide by this dictum, there is the continuing possibility for collaboration with the Waikato-Tainui people, including possibilities for both theoretical and practical research in language education and its links to self-determination.

\section{Reflections on Theory}

Three types of academic theory - the first regarding language maintenance, the second regarding underdevelopment, and the third regarding the impact of colonization on Indigenous peoples - have influenced Rakaumanga's development. Theories of language maintenance and language instruction have been of obvious benefit. Community members recall that, in the early 1980s, Professor John Moorfield visited the school and provided theoretical support for the community's drive to establish a Maori-language immersion program. Teachers have had ongoing instruction on first- and second-language acquisition and teaching. Secondary school students of the 1990s also remember intensive Maori language instruction from theoretically knowledgeable Professors Timoti Karetu and Wharehuia Milroy as well as other members of the Maori Language Commission.

However, the establishment, direction, and growth of this school cannot be explained only in terms of theories of language instruction and maintenance. For more than 30 years, Sir Robert Mahuta led the tribe in its struggle for a settlement of its claim relating to 19 th-century land confiscations. In the early 1970s, he studied for a doctorate at Oxford where he was introduced to Frank's (1971) theories of underdevelopment. As a result, he became convinced that the tribe's economic development would improve if the tribe's educational level increased. Development and education became the major themes of his life's work with the tribe. Although he passed away in 2001, his views continue to influence tribal members, including the school's teachers and members of the Runanga. The school's program has been closely connected to other programs of economic and social development within the tribe and the local community. One major reason for including both Western and Waikato-Tainui knowledge in the school's program is to prepare young people to participate in future tribal economic and social development. Frank's (1971) development theories, as disseminated by Sir Robert Mahuta, have had a direct impact on the way this school was established.

The third theory relevant to Rakaumanga was suggested by the principal, Barna Heremia, when we discussed the theoretical sections of this article with him. Heremia mentioned John Ogbu and pointed out that, "Ogbu talked about people who have been conquered. How does an Indigenous group that is a minority group dominated by an invader group assume its right to express itself as a people and get its knowledge and ways of knowing to be of benefit to the country where they reside?"

Before discussing the relevance of Ogbu's theoretical framework, academic achievement at Rakaumanga must be considered. Although we have focused on the school's incorporation of Waikato-Tainui knowledge, student achievement has been a major consideration for staff, parents, and students themselves. In New Zealand, the most important achievement measures are the national examinations that all students take at ages 15, 16, and 17. In its annual report on Maori education, 
the Ministry of Education (2003:Case Study 4) presented a brief case study on Te Wharekura o Rakaumangamanga. The report noted that the school was the largest Maori immersion school in New Zealand, teaching all subjects except English in Maori. Furthermore, the number of students taking senior examinations suggested a very low dropout rate. This school in a low socioeconomic community has excelled on national exams, with results comparable to schools in the wealthiest communities. It is important to note that high academic achievement has been characteristic of students from the Rakaumanga community only since the establishment of the secondary unit at the school.

When Ogbu first presented his explanation for minority achievement, he included a case study of Maori in New Zealand to support his proposition that lower academic performances of involuntary minorities were related to histories of conquest and barriers in the adult opportunity structure (1978:265-285). Ogbu's 1978 publication stimulated extensive research into the historical and political context of various minority groups and the extent to which his framework applied to these groups. When exceptions and questions emerged from the new studies, Ogbu adapted and elaborated on the original propositions. By 1998, Ogbu and Simons had proposed a cultural-ecological theory of minority school performance involving the "system" on the one hand and a second set of factors termed "community forces" on the other. However, exceptions to the new set of propositions emerged and more questions were raised. Kevin Foster (email to the Council on Anthropology listserv, February 4, 2004), summarized the major issues causing continuing controversy regarding the model. Gender differences, student resilience, and teacher caring are not well explained by the model. Moreover, neoconservatives have appropriated the model in ways not intended by Ogbu.

However, Ogbu and Simons (1998:155) offer their model as a heuristic device and not as a predictor of academic performance in every situation. Using their framework as a basis for the analysis of the Rakaumanga programs, we can infer that the development of the Maori immersion program and the inclusion of Waikato-Tainui epistemology in the curriculum became possible because of changes in both the wider system and the local community in the past 25 years. During this time, the New Zealand education system has changed in significant ways, responding to Maori demands for education in Maori language that incorporates Maori epistemology. Maori sections have been established in the central bureaucratic institutions that govern education. Funding has been made available for Maori-language instruction. Teacher colleges now train teachers for immersion schools, resulting in an increase in the number of Maori teachers in the schools. Boards of trustees have been established in each school with some authority to make decisions regarding staffing, curriculum, and expenditures. At Rakaumanga, this has allowed the community to have a greater say in what happens in the local school. The introduction of the NCEA allowed Rakaumanga to develop achievement standards that incorporate Waikato-Tainui knowledge and ways of knowing.

During the same period, instrumental beliefs, relational beliefs, and symbolic beliefs about schooling (Ogbu and Simons 1998:163) also changed. Influential Maori leaders, notably Sir Robert Mahuta, exhorted the local community to place a higher value on the educational achievement of their children so that children would grow up to play active roles in the economic and social development of the community. These leaders also served as role models for the younger generation. The community initiated a collective struggle for better education. On the basis of our years of experience in the day-to-day life of the school and community, we have concluded that the community's trust in the school grew when people from their own and other Maori tribes assumed teaching and leadership positions, and when the Indigenous language and epistemology were given central roles in the school. The school became a place of pride in Waikato-Tainui cultural and language differences where collective identity could be maintained. Community members no longer believed that schooling was a threat to their history, language, self-determination, or human rights. 
Ogbu and Simons's (1998) model has been useful in understanding the kinds of changes that have taken place in the cultural ecology of Rakaumanga, but the structural changes only opened options for the school. Ogbu's theory leaves involuntary minorities with the question raised by Rakaumanga's principal: How does an Indigenous group that is dominated by an invader group assume its right to self-expression as a people? Matua Heremia described the way that Rakaumanga has addressed this problem:

The key has been on manipulating policies and legislation to support what Te Wharekura has been ... about. We are using the existing framework to assert Waikato-Tainui identityso that students can get credits for it. Recently, we have taken a more structured approach to support the realization of our objectives.

Significantly, Ogbu and Simons observed that "Structural barriers and school factors affect minority school performance; however, minorities are also autonomous human beings who actively interpret and respond to their situation. Minorities are not helpless victims" (1998:158). There would be no Maori immersion or Waikato-Tainui epistemology in the school program without the dedicated, longterm effort and insight of talented individuals, particularly the principal, Barna Heremia, and the chairman of the Runanga, Taitimu Maipi. We believe that schools in other Indigenous settings can benefit from the grassroots experience of this school and its community.

Barbara Harrison is a retired senior research fellow, School of Maori and Pacific Development, University of Waikato (b.harrison@wave.co.nz). Rahui Papa is a secondary school teacher at Te Wharekura o Rakaumangamanga, is affiliated with Waikato and Raukawa tribes, and is a member of the Waikato-Tainui tribal government (rahui@rakaumanga. school.nz).

\section{Notes}

Acknowledgments. We are grateful to Harry F. Wolcott, anonymous reviewers, and the editors of this theme issue for constructive comments on an earlier draft of this article.

1. Maori refers to any member of an Indigenous tribe of New Zealand. Maori also is the name of the Indigenous language of these tribes, although dialectic differences among tribes exist. "Maori-language immersion school" means a school in which most subjects are taught in the Maori language: English is usually taught as a separate subject.

2. Primary schools in New Zealand are comparable to elementary schools in the United States.

3. In 2000, the name of the school was changed to Te Wharekura o Rakaumangamanga, but it is often referred to simply as Rakaumanga. A wharekura is a combined primary and secondary school. Rakaumangamanga is the name of the place where the original school was built, although it was moved to a new site in the 1970s.

4. For Waikato-Tainui and other tribes in New Zealand, small parcels of land became the basis of Maori community centers called marae.

\section{References Cited}

American Anthropological Association

1998 Code of Ethics of the American Anthropological Association. Electronic document, http:/ / www.aaanet.org/committees/ethics/ethcode.htm, accessed January 26, 2004. Aspin, Stanley Clive

1994 A Study of Mathematics Achievement in a Kura Kaupapa Maori. Master's thesis, Programme in Applied Linguistics, Victoria University of Wellington, New Zealand.

Barnhardt, Ray, and Anagayuqaq Oscar Kawagley

2004 Culture, Chaos and Complexity: Catalysts for Change in Indigenous Education. Cultural Survival Quarterly 27(4):59-64.

Biggs, Bruce

1995 Introduction. In Nga Iwi o Tainui: Nga Koorero Tuku Iho o Nga Tupuna: The Traditional History of the Tainui People. Pei Te Hurinui Jones and Bruce Biggs., eds. Pp. 1-9. Auckland, NZ: Auckland University Press. 
Frank, Andre Gunder

1971 Capitalism and Underdevelopment in Latin America: Historical Studies of Chile and Brazil. Harmondsworth, UK: Penguin.

Harrison, Barbara

1987 Rakaumanga School: A Study of Issues in Bilingual Education. Hamilton, NZ: Centre for Maaori Studies and. Research, University of Waikato.

1998 Te Wharekura o Rakaumangamanga: The Development of an Indigenous Language Immersion School. Bilingual Research Journal 22(2/3/4):297-316.

Jones, Pei Te Hurinui

1945 Mahinarangi (The Moon-Glow of the Heavens): A Tainui Saga. Hawera, NZ: J. C. Ekdahl.

1958 Maori Genealogies. Journal of the Polynesian Society 67(2):162-165.

1960 King Potatau: An Account of the Life of Potatau Te Wherowhero, The First Maori King. Wellington, NZ: The Polynesian Society.

Jones, Pei Te Hurinui, and Bruce Biggs

1995 Nga Iwi o Tainui: Nga Koorero Tuku Iho o Nga Tupuna: The Traditional History of the Tainui People. Auckland, NZ: Auckland University Press.

Kelly, Leslie G.

2002[1949] Tainui: The Story of Hoturoa and His Descendants. Christchurch, NZ: Cadsonbury.

McCan, David

2001 Whatiwhatihoe: The Waikato Raupatu Claim. Wellington, NZ: Huia Publishers.

Ministry of Education

2003 Nga Haeata Matauranga: Annual Report on Maori Education 2001/2002 and

Direction for 2003. Electronic document, http://www.minedu.govt.nz/index.cfm? layout $=$ document\&documentid $=8438 \&$ indexid $=6504 \&$ indexparentid $=1063$, accessed January 30, 2004.

Ogbu, John U.

1978 Minority Education and Caste: The American System in Cross-Cultural Perspective. New York: Academic Press.

Ogbu, John U., and Herbert D. Simons

1998 Voluntary and Involuntary Minorities: A Cultural-Ecological Theory of School Performance with Some Implications for Education. Anthropology and Education Quarterly 29(2):155-188.

Rogers, Neil Gregory

2003 Kia Whakapakari Ngaa Kaiako Paangarau ki Roto i Tetahi Wharekura Kaupapa Maaori: Professional Development of Mathematics Teachers in a Maaori Immersion School. Master's thesis, School of Education, University of Waikato.

Salmond, Anne

1985 Maori Epistemologies. In Reason and Morality. Joanna Overing, ed. Pp. 240-263. London: Tavistock.

Smith, Linda Tuhiwai

1999 Decolonizing Methodologies: Research and Indigenous Peoples. London: Zed Books Ltd.

Statistics New Zealand

2001 Census: Table 1, Maori Population Summary 1858-2001. Electronic document, http://www.stats.govt.nz/domino/external/pasfull/pasfull.nsf/7cf46ae26dcb6800cc256a62000a2248/4c2567ef00247c6acc256bf900106d23? Open Document, accessed February 17, 2004.

Tainui Maaori Trust Board

1991 Tainui Education Strategy, Second Report, 1992-1997. Ngaruawahia, NZ: Tainui Maaori Trust Board.

Tuteao, Verna

1998 Maaku Anoo e Hanga Tooku nei Whare: Ko Ngaa Pou o Roto, he Maahoe, he Patatee, ko te Taahuhu he Hiinau: Te Wharekura Kaupapa Maaori aa Rohe o Raakaumangamanga. [I Shall Build a House; the Ridgepole Will Be of Hinau and the Supporting Posts of Maahoe, Patete: The Combined Primary and Secondary MaoriCentered School of the Region of Rakaumangamanga.] Master's thesis, Department of Education, University of Auckland.

Walker, Ranginui

1990 Ka Whawhai Tonu Matou: Struggle without End. Auckland, NZ: Penguin. 